Selcuk Journal of Agriculture and Food Sciences

$\underline{\text { http://sjafs.selcuk.edu.tr/sjafs/index }}$

Research Article
SJAFS

(2019) 33 (3), 215-222

e-ISSN: 2458-8377

DOI:10.15316/SJAFS.2019.178

\title{
Determination of Fuel Properties of Some Alcohols (Bioethanol, Butanol), Biodiesel and Diesel Mixtures Obtained from Anchovy (Engraulis encrasicolus) Oil
}

\author{
Abdullah KARABOĞA*, Hakan Okyay MENGEŞ ${ }^{1}$ \\ ${ }^{1}$ Selçuk University, Faculty of Agriculture, Department of Soil Science and Plant Nutrition, Konya, Turkey

\begin{tabular}{l}
\hline ARTICLE INFO \\
\hline Article history: \\
Received date: 27.07 .2019 \\
Accepted date: 06.08.2019 \\
\hline Edited by: \\
Osman ÖZBEK; Selçuk University, \\
Turkey \\
Reviewed by: \\
Hidayet OĞUZ; Necmettin Erbakan \\
University, Turkey \\
Tanzer ERYILMAZ; Yozgat Bozok \\
University, Turkey \\
\hline
\end{tabular}

ABSTRACT
In this study, some alcohols (bioethanol, butanol) are mixed with different
amounts in volume $\left(\mathrm{D}_{100}, \mathrm{~B}_{100}, \mathrm{D}_{75} \mathrm{~B}_{20} \mathrm{E}_{5}, \mathrm{D}_{70} \mathrm{~B}_{20} \mathrm{E}_{10}, \mathrm{D}_{65} \mathrm{~B}_{20} \mathrm{E}_{15}, \mathrm{D}_{75} \mathrm{~B}_{20} \mathrm{BU}_{5}\right.$,
$\mathrm{D}_{70} \mathrm{~B}_{20} \mathrm{BU}_{10}$ and $\left.\mathrm{D}_{65} \mathrm{~B}_{20} \mathrm{~B} \mathrm{U}_{15}\right)$ some physical and chemical fuel properties of
diesel, biodiesel and obtained alcohol + biodiesel + diesel blend fuels (Density,
Kinematic viscosity, Flash point, Water content, Copper strip corrosion, Cloud
point, Pour point, Cold filter plugging point (CFPP), The thermal value) was
determined.According to the results of the research, it was observed that the
physical and chemical fuel properties of biodiesel and blended fuels were
within the standard fuel properties. The cetane number of $\mathrm{D}_{65} \mathrm{~B}_{20} \mathrm{E}_{15}$ fuels was
$12 \%$ lower than the diesel standard (TS $3082 \mathrm{EN} 590)$. In addition, when cold
flow properties were examined, it was determined that ethanol and butanol
added to fuels contributed positively.

Keywords:

Anchovy Oil,

Biodiesel,

Mixture Ratios,

Fuel Properties

\section{Introduction}

Energy is one of the major consumption elements of our age and is one of the basic elements of civilization. As the world population increases, industrialization activities and hence the demand for energy are increasing.In parallel with the development level of the countries, the energy use and the increasing demand for energy in order to meet the energy needed, the orientation to renewable energy sources has also gradually accelerated. In the future, this trend is expected to continue increasingly (Anonymous, 2012).

Bioenergy is an important place among renewable energy sources.Figure 1 shows the development of bioenergy installed capacity in the world between 2010 and 2018. As can be seen, the total bioenergy installed capacity in the world has increased steadily over the years.

The total installed capacity in 2010 was 66.926 MW while the total installed capacity in 2018 was 115.731 MW.Liquid biofuel installed capacity, which is one of the bioenergy types, increased from 1.856

\footnotetext{
* Corresponding author email: mail@abdullahkaraboga.com
}

MW in 2010 to $2.352 \mathrm{MW}$ in 2018 with an increase of 26 percent (Anonymous, 2019).

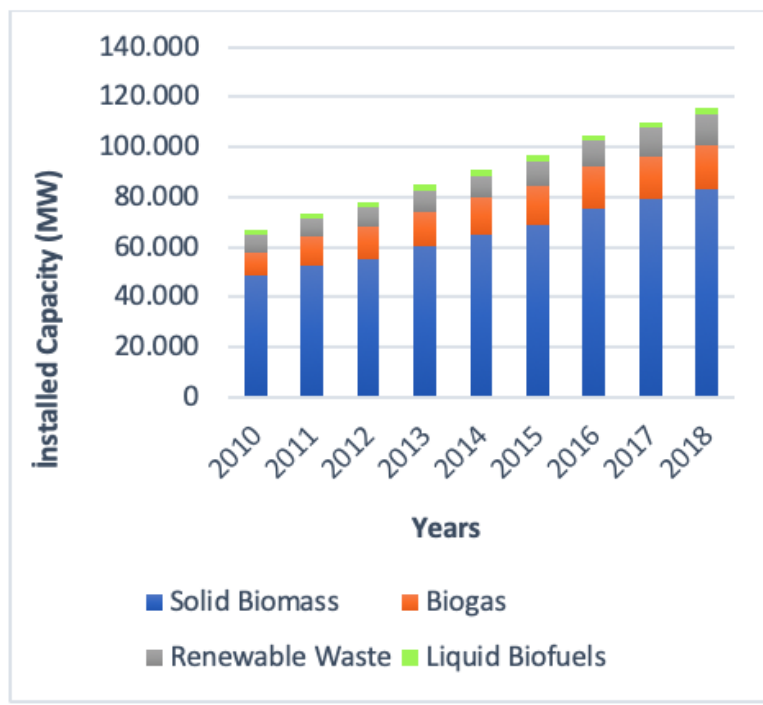

Figure 1

Energy capacity installed on earth

In internal combustion engines, alcohols, liquefied petroleum gas, compressed or liquefied natural gas, vegetable and animal oils and biodiesel derived from 
these oils can be used as alternative fuels (Sekmen and Şen, 2016). Biodiesel is a fuel that contains complex chemicals consisting of new or unnecessary vegetable oils and animal fats and that is made in the engine with mixing ratio ratio with diesel fuel (Eryilmaz, 2009).

Today, in biodiesel production, the usage of nonconsumed waste oils, which are not consumed in other words, instead of vegetable and animal fats used as direct nutrients, constitutes an important alternative for countries such as our country, which obtain a portion of their edible oil needs through imports. In this context, considering the zero waste food policy, the part of the fish, seperated as waste throughout the world is considerable amount (Sekmen and Sen, 2016)

According to FAO (Food and Agriculture Organization) data, 90 million 923 thousand tons with fisheries and 80 million 70 thousand with aquaculture and total 170 million 995 thousand tons of fish was produced in the world in 2016, (Anonymous, 2018). In Turkey, 354 thousand fish by hunting, 276 thousand tons fish by aquaculture and total 630 thousand tons fish produced at 2017 (Tuik 2017, TOB 2019). It is reported that; approximately $50 \%$ of processed fish become (gills, fin, internal organs and head) as waste. (Yayhaee et al., 2013)

Considering the cost of biodiesel production, $60-75$ $\%$ of the total cost, such as a large portion of the raw material used (oil and alcohol) costs constitute. For this reason, the use of non-consumed and waste oils in biodiesel production will contribute significantly to reduce production costs. Considering these and similar reasons, it is seen that studies on improving the production and quality of biodiesel from animal fats which are not consumed or used waste have been given importance recently (Guru et al.,2010; Sekmen and Sen, 2016).

In this study, fuel properties of some alcohols (Bioethanol, Butanol), biodiesel (AOME) and diesel mixtures were determined.

\section{Materials and Methods}

\subsection{Material}

In the study, anchovy oil obtained from Anchovy (Engraulis encrasicolus) fish, bioethanol and butanol were used as diesel and alcohol to be added to these fuels. Figures 2, 3 and 4, respectively, filtered oil of anchovy and mixtures with diesel, bioethanol and butanol.

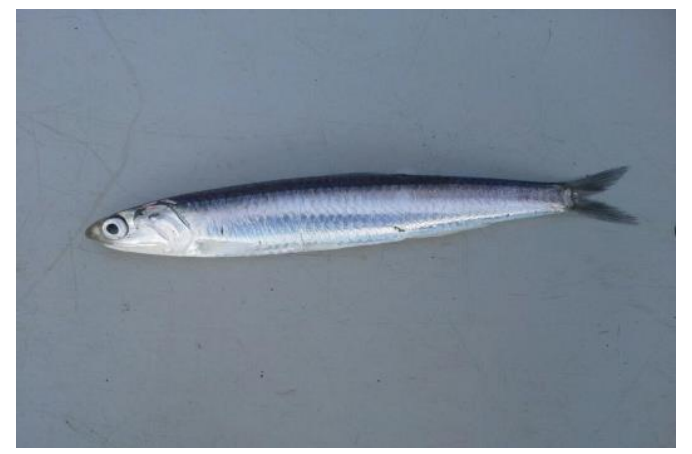

Figure 2

Anchovy (Engraulis encrasicolus) fish

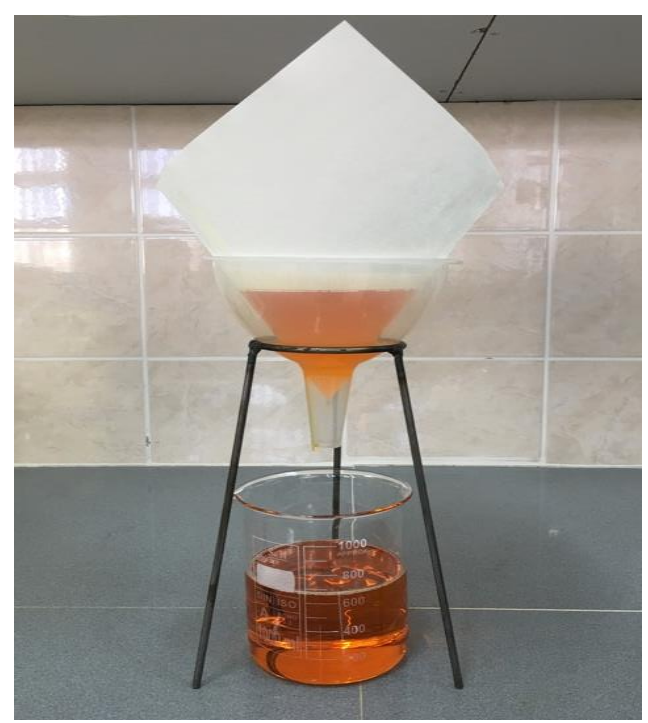

Figure 3

Filtered anchovy oil

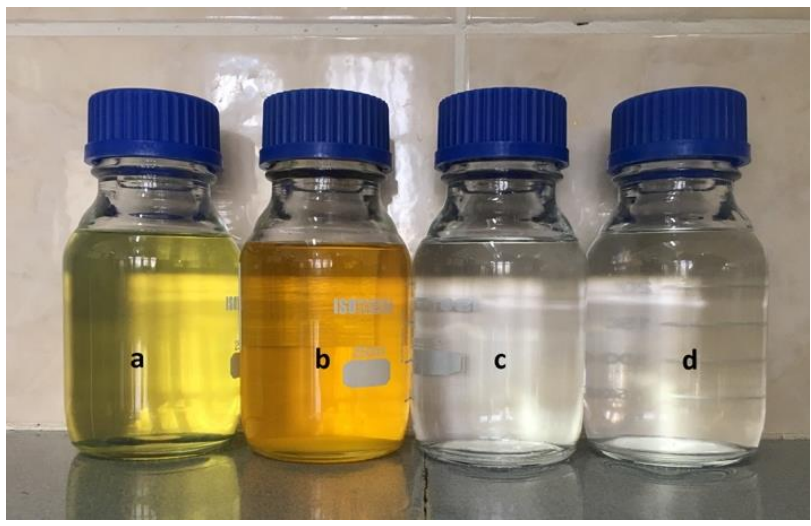

Figure 4

Diesel (a), Biodiesel (b), Bioethanol (c) Butanol (d)

\subsection{Method}

Anchovy oil was used as raw material in biodiesel production (Figure 3 ). In the production phase, one of the biodiesel production methods, transesterification method was used (Öğ̈̈t and Oğuz, 2006).

\subsubsection{Obtaining Methyl Ester from Anchovy Oil}

With the method of transesterification anchovy oil was produced after determining necessary alcohol and catalyst quantities for 1 litre raw oil. Accordingly, quantity of $20 \%$ methyl alcohol $(200 \mathrm{ml})$ and $4.7 \mathrm{gr}$ 
sodium hydroxide catalyst was determined (Sekmen ve Şen, 2016). Methyl alcohol and sodium hydroxide was blend in an appropriate cover till melted and methoxide was acquired. This mixture was added to raw oil which is heated at $60{ }^{\circ} \mathrm{C}$ in a heater with thermostat controlled and magnetic mixer and it was mixed homogenously.

Acquired mixture was kept for falling after mixing for two hour. At the end of the precipitation process, one of the two products, which had been deposited underneath, was taken.Biodiesel which is isolated from glycerol was rinsed with pure water. Rinsing process was performed with misting unit by using pure water at $50{ }^{\circ} \mathrm{C}$ with the quantity of $20 \%$ of raw biodiesel (during rinsing biodiesel is $50{ }^{\circ} \mathrm{C}$, water is $50{ }^{\circ} \mathrm{C}$ ). Biodiesel was prepared as availlable after drying process. The AOME obtained at the end of the production process is shown in figure 5 .

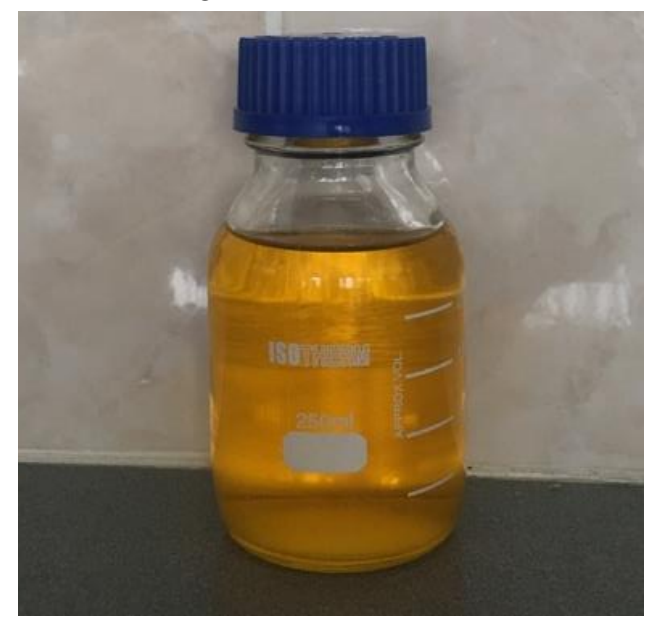

Figure 5

AOME produced as a result of transesterification reaction

2.2.2 Preparation of Anchovy Oil Methyl Ester, Alcohols (bioethanol and butanol) and Diesel Mixtures

Mixture fuels were prepared by volume in certain proportions, anchovy oil methyl ester produced by transesterification method was added to diesel fuel and then alcohol was added.

The obtained mixture was mixed with homogenizer for 10 minutes and a homogeneous mixture was obtained at the end of this period.Table 1 shows the amount of mixing ratios as a percentage and Figure 6 shows the mixture fuels prepared.

Table 1

Diesel, biodiesel and alcohol mixture rates

\begin{tabular}{lcccc}
\hline $\begin{array}{l}\text { Mixture } \\
\text { Name }\end{array}$ & $\begin{array}{c}\text { Diesel } \\
(\mathrm{D}) \\
(\%)\end{array}$ & $\begin{array}{c}\text { Biodiesel } \\
(\mathrm{B}) \\
(\%)\end{array}$ & $\begin{array}{c}\text { Bioetha- } \\
\text { nol(E) } \\
(\%)\end{array}$ & $\begin{array}{c}\text { Buta- } \\
\text { nol(BU) } \\
(\%)\end{array}$ \\
\hline $\mathrm{D}_{100}$ & 100 & - & - & - \\
$\mathrm{B}_{100}$ & - & 100 & - & - \\
$\mathrm{D}_{75} \mathrm{~B}_{20} \mathrm{E}_{5}$ & 75 & 20 & 5 & - \\
$\mathrm{D}_{70} \mathrm{~B}_{20} \mathrm{E}_{10}$ & 70 & 20 & 10 & - \\
$\mathrm{D}_{65} \mathrm{~B}_{20} \mathrm{E}_{15}$ & 65 & 20 & 15 & - \\
$\mathrm{D}_{75} \mathrm{~B}_{20} \mathrm{BU}_{5}$ & 75 & 20 & - & 5 \\
$\mathrm{D}_{70} \mathrm{~B}_{20} \mathrm{BU}_{10}$ & 70 & 20 & - & 10 \\
$\mathrm{D}_{65} \mathrm{~B}_{20} \mathrm{BU}_{15}$ & 65 & 20 & - & 15 \\
\hline
\end{tabular}

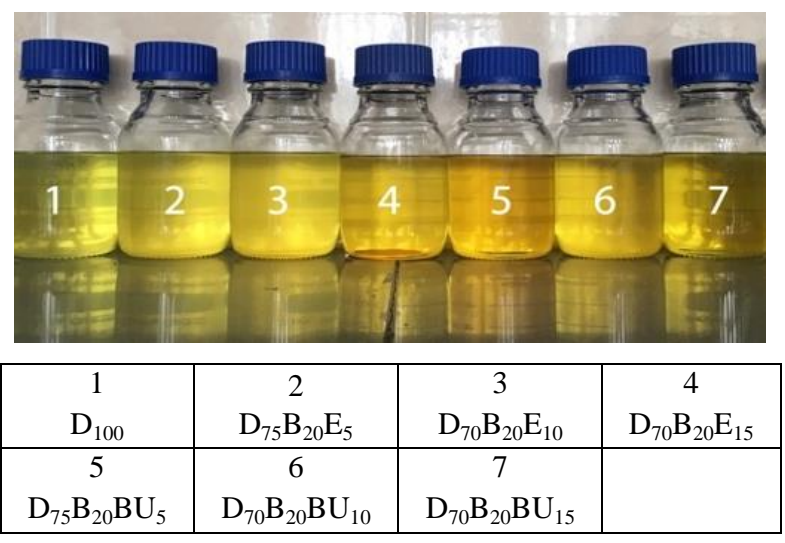

Figure 6

Fuel and mixtures used in the research

\subsubsection{Determination of Fuel Properties of Fuels and} Their Mixtures

During the research, fuel analysis laboratory of Selçuk University, Faculty of Agriculture, Department of Agricultural Machinery and Technologies was used to determine the fuel properties(Density, Kinematic viscosity, Flash point, Water content, Copper strip corrosion, Number of acids, Cloud point, Pour point, Cold filter plugging point (CFPP), Thermal value) of fuels and mixtures. The results of the analysis were compared to standards TS EN 14214 for anchovy oil methyl ester and TS 3082 EN 590 standards for mixtures and diesel.

\section{Results and Discussion}

As a result of the analyzes, the fatty acid concentration values of the anchovy oil determined are given in Table 2 and the fuel properties of raw oil, diesel and mixture fuels are given in Table 3 . In addition, TS EN 14214, TS EN 14213 and TS 3082 EN 590 standards are shown in Tables 4, 5 and 6 respectively.

Table 2

Anchovy oil fatty acids concentration

\begin{tabular}{lcc}
\hline Fatty Acid & \multicolumn{2}{c}{ Anchovy Oil Concentration } \\
\hline Myristic acid & (C14:0) & 6 \\
Palmitic acid & $(\mathrm{C} 16: 0)$ & 23.5 \\
Stearic acid & $(\mathrm{C} 18: 0)$ & 4.5 \\
Oleic acid & $(\mathrm{C} 18: 1)$ & 24.5 \\
Linoleic acid & $(\mathrm{C} 18: 2)$ & 3 \\
Arachidic acid & $(\mathrm{C} 20: 0)$ & 0.148485 \\
Erucic acid & $(\mathrm{C} 22: 1)$ & 0.79828 \\
\hline
\end{tabular}

Sekmen and Sen, (2016), in their study, obtained similar results to the results given in Table 2 .

\subsection{Fuel Properties of Anchovy Oil, Anchovy Oil Methyl Esther, Diesel and Fuel Mixtures}

As seen in Table 3, because of the viscosity of the crude oil is high $\left(28.4 \mathrm{~mm}^{2} / \mathrm{s}\right)$ firstly the viscosity of the oil was reduced to standard value (TS EN 14214) by the transesterification method $\left(4.55 \mathrm{~mm}^{2} / \mathrm{s}\right)$ and then the mixture of fuel by preparing the mixture fuel properties of fuels were determined. It is observed that; viscosity values decreased with increasing amount of diesel, bioethanol and butanol added to the produced anchovy oil methyl ester. This can be attributed to the 
low viscosity of the used diesel and alcohols (bioethanol and butanol).

As it can be seen from Table 3, when the cetane number values of mixture fuels are examined, it is seen that the cetane number values of all fuels except $\mathrm{D}_{65} \mathrm{~B}_{20} \mathrm{E}_{15}$ fuel exceed the diesel standard (EN 590) value (at least 51.0). It is reported that ethanol has a negative effect on the ignition characteristics of diesel fuel in mixture ratios above $10 \%$ due to its very low cetane number and therefore cetane enhancers should be used (Yahuza and Dandakouta, 2015; Sezer, 2017). In general, cetane numbers of butanol mixtures are higher than ethanol mixtures. This can be attributed to the cetane number of butanol higher than ethanol.
The high consistency of anchovy oil decreased considerably after conversion to the methyl ester form and this fall continued in the mixture fuels. Consistency of anchovy oil, which was $922.2 \mathrm{~kg} / \mathrm{m}^{3}$, decreased to 895 $\mathrm{kg} / \mathrm{m}^{3}$ after conversion to methyl ester. As can be seen in the table, the density values of the fuels and their mixtures were found within the limits of the standard (TS EN 14214). When the consistency values of all mixture fuels are examined, it is seen that these values are between the standards (TS $3082 \mathrm{EN} \mathrm{590)} \mathrm{values} \mathrm{of}$ diesel (minimum $820 \mathrm{~kg} / \mathrm{m}^{3}$, maximum $845 \mathrm{~kg} /$ $\left.\mathrm{m}^{3}\right)$.

Table 3

$\mathrm{D}_{100}, \quad \mathrm{~B}_{100}, \quad \mathrm{D}_{75} \mathrm{~B}_{20} \mathrm{E}_{5}, \quad \mathrm{D}_{70} \mathrm{~B}_{20} \mathrm{E}_{10}, \quad \mathrm{D}_{75} \mathrm{~B}_{20} \mathrm{BU}_{5}, \quad \mathrm{D}_{70} \mathrm{~B}_{20} \mathrm{BU}_{10}, \quad \mathrm{D}_{65} \mathrm{~B}_{20} \mathrm{BU}_{15}$, crude oil and diesel fuel properties

\begin{tabular}{|c|c|c|c|c|c|c|c|c|c|}
\hline Fuel properties & $\mathrm{D}_{100}$ & $\mathrm{~B}_{100}$ & $\mathrm{D}_{75} \mathrm{~B}_{20} \mathrm{E}_{5}$ & $\mathrm{D}_{70} \mathrm{~B}_{20} \mathrm{E}_{10}$ & $\mathrm{D}_{65} \mathrm{~B}_{20} \mathrm{E}_{15}$ & $\mathrm{D}_{75} \mathrm{~B}_{20} \mathrm{BU}_{5}$ & $\mathrm{D}_{70} \mathrm{~B}_{20} \mathrm{BU}_{10}$ & $\mathrm{D}_{65} \mathrm{~B}_{20} \mathrm{BU}_{15}$ & $\begin{array}{c}\text { Crude } \\
\text { Oil }\end{array}$ \\
\hline \multicolumn{10}{|l|}{ Kinematic } \\
\hline $\begin{array}{l}\text { Viscosity } \\
\left(\mathrm{mm}^{2} / \mathrm{s}\right)\left(40^{\circ}\right. \\
\text { C) }\end{array}$ & 3.052 & 4.55 & 2.834 & 2.737 & 2.663 & 2.956 & 2.854 & 2.780 & 28.4 \\
\hline $\begin{array}{l}\text { Density } \mathrm{kg} / \mathrm{m}^{3} \\
\left(15{ }^{\circ} \mathrm{C} \mathrm{de}\right)\end{array}$ & 835.0 & 895.1 & 838.8 & 837.3 & 835.3 & 838.4 & 837.3 & 835.8 & 922.2 \\
\hline $\begin{array}{l}\text { Net Heat Com- } \\
\text { bustion } \\
\text { (MJ/kg) }\end{array}$ & 46.335 & 39.720 & 42.688 & 41.989 & 41.202 & 44.576 & 43.597 & 43.216 & - \\
\hline $\begin{array}{l}\text { Flash Point }\left(^{\circ}\right. \\
\text { C) }\end{array}$ & 57 & 147 & - & - & - & - & - & - & - \\
\hline $\begin{array}{l}\text { Water Content } \\
(\mathrm{ppm})\end{array}$ & 17.887 & 183.13 & 246.27 & 392.58 & 441.06 & 86.066 & 106.321 & 123.172 & 651 \\
\hline $\begin{array}{l}\text { Copper Strip } \\
\text { Corrosion }\end{array}$ & $1 \mathrm{a}$ & $1 \mathrm{a}$ & $1 \mathrm{a}$ & $1 \mathrm{a}$ & $1 \mathrm{a}$ & $1 \mathrm{a}$ & $1 \mathrm{a}$ & $1 \mathrm{a}$ & - \\
\hline Cloud Point & -4.5 & 8 & -3 & -3.8 & -4.4 & -3.1 & -4.9 & -6.5 & - \\
\hline CFPP & -16 & 7 & -4 & -6 & -7 & -5 & -6 & -7 & - \\
\hline Pour Point & -26 & 6 & -7.1 & -8.9 & -9.9 & -8.4 & -9.5 & -11.2 & - \\
\hline Cetane Number & 53.717 & - & 52.344 & 51.877 & 44.149 & 53.249 & 53.682 & 53.359 & - \\
\hline
\end{tabular}

According to the analysis results of fuels obtained from mixtures of bioethanol, butanol and diesel fuel with anchovy oil biodiesel, the water content values of mixture fuels $\left(\mathrm{D}_{75} \mathrm{~B}_{20} \mathrm{E}_{5}, \mathrm{D}_{70} \mathrm{~B}_{20} \mathrm{E}_{10}, \mathrm{D}_{65} \mathrm{~B}_{20} \mathrm{E}_{15}\right)$ prepared only by adding bioethanol did not show compliance with diesel standard (TS $3082 \mathrm{EN}$ 590) values. $\mathrm{D}_{75} \mathrm{~B}_{20} \mathrm{E}_{5}, \mathrm{D}_{70} \mathrm{~B}_{20} \mathrm{E}_{10}, \mathrm{D}_{65} \mathrm{~B}_{20} \mathrm{E}_{15}$ ) compared to the standard value (up to 200 ppm) 23\%, 46\% and $120 \%$ respectively. This can be explained by the high water content of bioethanol in the mixture fuels. Balc1 (2017) found similar results in his study.

In addition, when the water content values of the mixture fuels were examined, it was observed that the water content values increased in parallel with the increase in the alcohol content in the mixture. For example, in blend fuels, these values were determined as $246.27 \mathrm{ppm}\left(\mathrm{E}_{5}\right), 392.58 \mathrm{ppm}\left(\mathrm{E}_{10}\right)$, and $441.06 \mathrm{ppm}$ $\left(\mathrm{E}_{15}\right)$ in bioethanol mixtures, $86.066 \mathrm{ppm}\left(\mathrm{BU}_{5}\right)$, $106.321 \mathrm{ppm}\left(\mathrm{BU}_{10}\right)$ and $123.172 \mathrm{ppm}\left(\mathrm{BU}_{15}\right)$ in buta- nol mixtures. In addition, water content values of butanol in the high alcohol group were lower than the bioethanol in the low alcohol group. This can be attributed to the fact that butanol is more hydrophobic than bioethanol (Kumar and Saravanan, 2016).

When the thermal values of the mixture fuels are examined, it is seen that there is a slight decrease in the thermal values compared to the increased bioethanol and butanol ratios in the mixtures. In addition, a slight increase was observed in the thermal values of the mixture fuels obtained by the addition of butanol compared to the mixture fuels containing bioethanol. Kumar and Saravanan (2016) stated that butanol has a higher thermal value compared to bioethanol.

Flash point is an important value for storage and transportation of fuel. The anchovy oil biodiesel has a flash point of $147{ }^{\circ} \mathrm{C}$ and a diesel fuel of $57{ }^{\circ} \mathrm{C}$. The flash point value of anchovy oil biodiesel was higher than ASTM 6751 and EN 14214 standards. 
Table 4

TS EN 14214 automotive fuels -fatty acid methyl esters (fame/biodiesel) - diesel engines - standarts

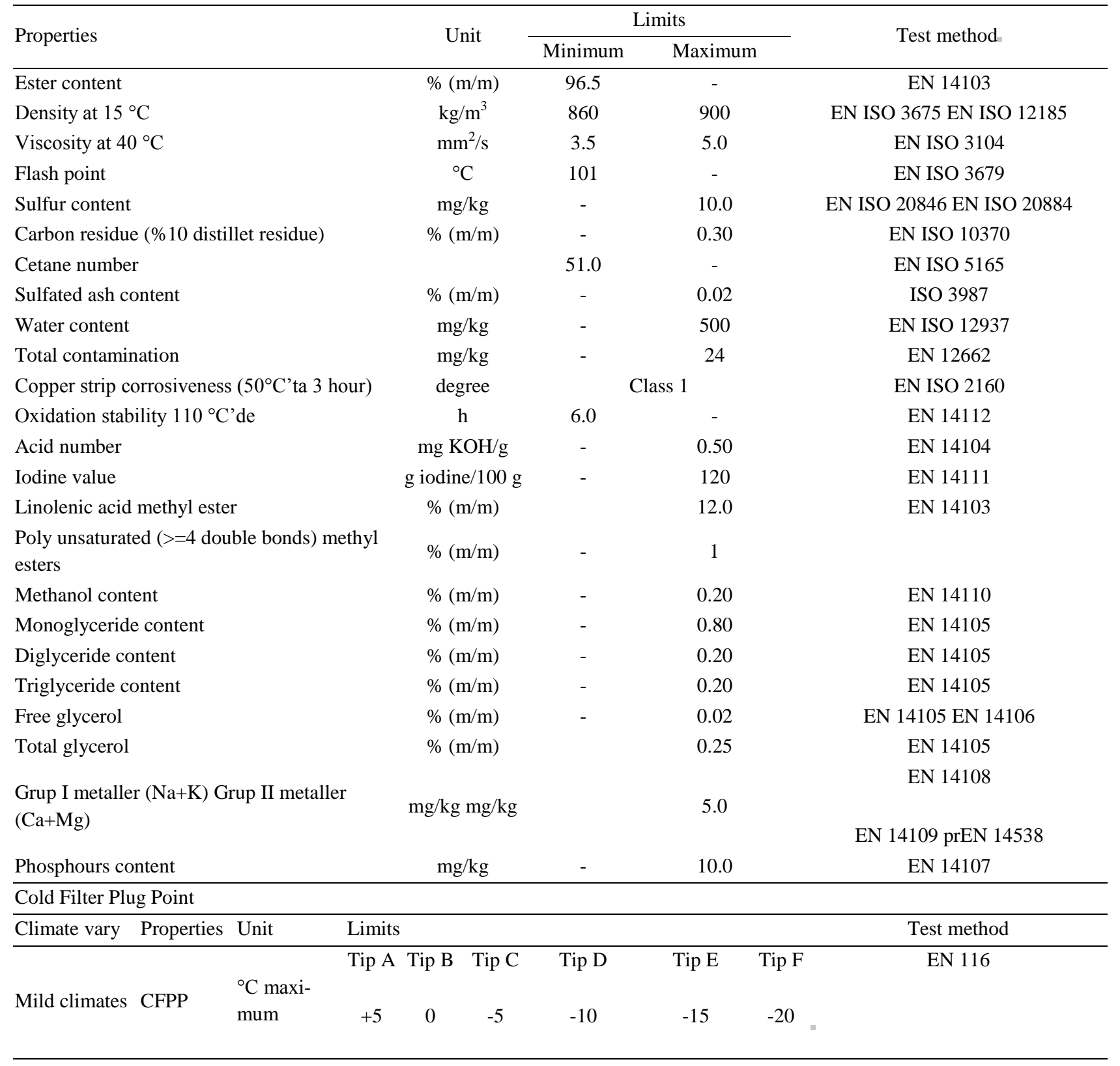


Table 5

TS EN 14213 heating fuels - fatty acid methyl esters (fame) standards

\begin{tabular}{|c|c|c|c|c|}
\hline \multirow{2}{*}{$\begin{array}{l}\text { Properties } \\
\text { Ester content }\end{array}$} & \multirow{2}{*}{$\begin{array}{c}\text { Unit } \\
\%(\mathrm{~m} / \mathrm{m})\end{array}$} & \multicolumn{2}{|c|}{$\begin{array}{c}\text { Limits } \\
\text { Minimum Maximum }\end{array}$} & \multirow{2}{*}{$\begin{array}{c}\text { Test method } \\
\text { EN } 14103\end{array}$} \\
\hline & & 96.5 & - & \\
\hline Density at $15{ }^{\circ} \mathrm{C}$ & $\mathrm{kg} / \mathrm{m}^{3}$ & 860 & 900 & EN ISO 3675 EN ISO 12185 \\
\hline Viscosity at $40^{\circ} \mathrm{C}$ & $\mathrm{mm}^{2} / \mathrm{s}$ & 3.5 & 5.0 & EN ISO 3104 ISO 3105 \\
\hline Flash point & ${ }^{\circ} \mathrm{C}$ & 120 & - & EN ISO 3679 \\
\hline Sulfur content & $\mathrm{mg} / \mathrm{kg}$ & - & 10.0 & EN ISO 20846 EN ISO 20884 \\
\hline Carbon residue ( $\% 10$ distillet residue) & $\%(\mathrm{~m} / \mathrm{m})$ & - & 0.30 & EN ISO 10370 \\
\hline Sulfated ash content & $\%(\mathrm{~m} / \mathrm{m})$ & - & 0.02 & ISO 3987 \\
\hline Water content & $\mathrm{mg} / \mathrm{kg}$ & - & 500 & EN ISO 12937 \\
\hline Total contamination & $\mathrm{mg} / \mathrm{kg}$ & - & 24 & EN 12662 \\
\hline Oxidation stability $110^{\circ} \mathrm{C} ' \mathrm{de}$ & $\mathrm{h}$ & 4.0 & - & EN 14112 \\
\hline Acid number & $\mathrm{mg} \mathrm{KOH} / \mathrm{g}$ & - & 0.50 & EN 14104 \\
\hline Iodine value & $\begin{array}{l}\mathrm{g} \text { iodine } / 100 \\
\mathrm{~g}\end{array}$ & - & 130 & EN 14111 \\
\hline $\begin{array}{l}\text { Poly unsaturated (>=4 double bonds) } \\
\text { methyl esters }\end{array}$ & $\%(\mathrm{~m} / \mathrm{m})$ & - & 1 & \\
\hline Monoglyceride content & $\%(\mathrm{~m} / \mathrm{m})$ & - & 0.80 & EN 14105 \\
\hline Diglyceride content & $\%(\mathrm{~m} / \mathrm{m})$ & - & 0.20 & EN 14105 \\
\hline Triglyceride content & $\%(\mathrm{~m} / \mathrm{m})$ & - & 0.20 & EN 14105 \\
\hline Free glycerol & $\%(\mathrm{~m} / \mathrm{m})$ & - & 0.02 & EN 14105 EN 14106 \\
\hline Cold Filter Plug Point (CFPP) & ${ }^{\circ} \mathrm{C}$ & - & & EN 116 \\
\hline Pour point & ${ }^{\circ} \mathrm{C}$ & - & 0 & ISO 3016 \\
\hline Net Heat Combustion ( counted) & $\mathrm{MJ} / \mathrm{kg}$ & 35 & - & $\begin{array}{l}\text { DIN 51900-1 DIN 51900-2 DIN } \\
51900-3\end{array}$ \\
\hline
\end{tabular}


Table 6

TS 3082 EN 590 automotive fuels - diesel(diesel fuel) Standard

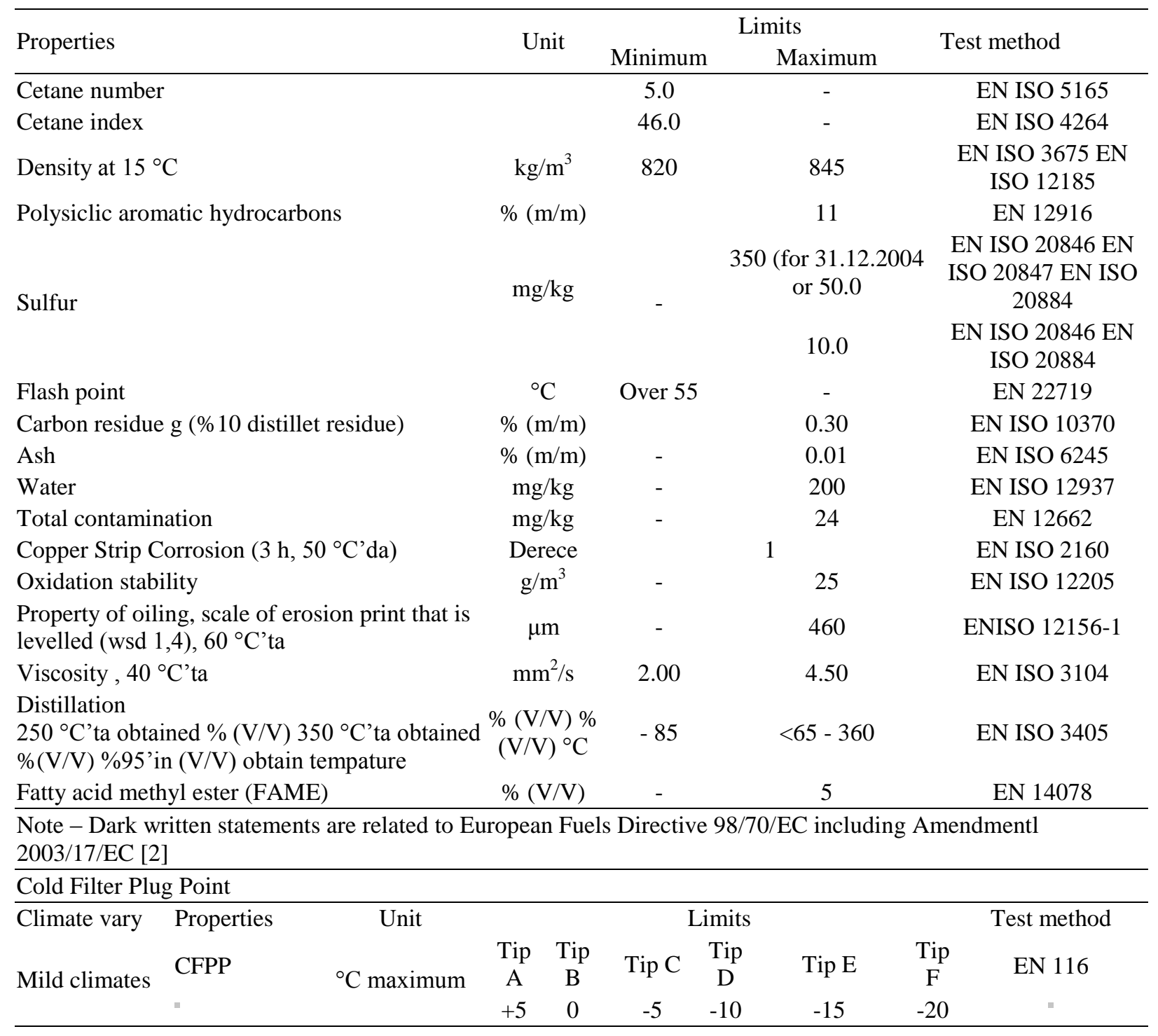

Animal oils are more disadvantageous in terms of cold flow properties compared to vegetable oils. In order to use biodiesel produced from animal fats in cold winter conditions, it may be necessary to use cold flow improving additives (Altun and Öner, 2008). When the $\mathrm{B}_{100}$ fuel is examined, it is seen that the values of cold flow properties are very high. Diesel fuel and alcohol were added to the mixture fuels to eliminate these problems.

The results of the analysis were compared to standards TS EN 14214 for anchovy oil methyl ester and TS 3082 EN 590 standards for mixtures and diesel.

\section{Acknowledgements}

This study is summarized from Abdullak KARABOGa's Master's thesis.

\section{References}

Akay ME (2007). Dizel - Elektrik Lokomotiflerde Biyodizel Uygulamas1. 1. Ulusal Yağl1 Tohumlu Bitkiler ve Biyodizel Sempozyumu, sayfa 20-25, Samsun.

Altun Ş, Öner C (2008). Hayvansal İç Yağlardan Transesterifikasyon Reaskiyonu ile Biyodizel Üretilmesi, Doğu Anadolu Bölgeleri Araştırmaları, 2008.

Anonymous (2012). Yenilenebilir enerji teknolojileri, yenilenebilir enerji kaynakları ve önemi, 522EE0421, T.C. Milli Eğitim Bakanlığı, Ankara.

Anonymous (2018). Food And Agriculture Organization, Dünyada Balıkçılık ve Su Ürünleri Yetiştiriciliğinin Durumu, http://www.fao.org/3/CA0191TR/ca0191tr.pdf

Anonymous (2019). İRENA,2019, "Installed Capacity Trend", https://www.irena.org/bioenergy, 2019

Gürü M, Koca A, Can Ö, Çınar C, Şahin F (2010). "Biodiesel production from waste chicken fat based sources and evaluation with $\mathrm{mg}$ based additive in a 
diesel engine", Renewable Energy, Cilt 35, No 3, 637-643, 2010.

Karahan Ş (2005). Biyodizel Kalitesi ve Biyodizel Kalitesinin Dizel Motorlara Etkileri. Türkiye'de Biyodizel Üretimindeki Mevcut Durum, Sorunlar ve Öneriler Çalıştayı, TÜBİTAK - Marmara Araştırma Merkezi, Enerji Enstitüsü, 02 Aralık, Ankara

Koç A, Yağlı H, Koç Y, Uğurlu İ (2018). "Dünyada ve Türkiye'de Enerji Görünümünün Genel Değerlendirmesi", Mühendis ve Makine, cilt 59, Sayı 692, s. 86-114, 2018.

Kumar R, Saravanan S (2016). Use of higher alcohol biofuels in diesel engine: A review, Renewable and Sustainable Energy Reviesw 60 (2016) 84-115

Öğüt H, Oğuz H (2006). Üçüncü milenyum yakıtı: biyodizel, 2. Bask1, Nobel Yayınları, Konya, p.

Sekmen Y, Şen S (2016). Gazi Üniv. Müh. Mim. Fak. Der. Journal of the Faculty of Engineering and
Architecture of Gazi University Cilt 31, No 1, 1927, 2016

Sezer İ (2017). Isı Bilimi ve Tekniği Dergisi, 37,1,6168.

Eryılmaz T (2009). Hardal yağı biyodizelinde farklı karışım oranlarının dizel motorlarda performansa etkisi, Doktora Tezi Selçuk Üniversitesi, Fen Bilimleri Enstitüsü, Konya

TOB (2019). Türkiye Cumhuriyeti Tarım ve Orman Bakalnlığı, Su ürünleri istatistikleri, 2019

Tüik (2017). Türkiye İstatistik Kurumu, 2019

Yahuza I, Dandakouta H (2015). A performance rewiew of ethanol-diesel blended fuel samples in compression-ignition engine, Journal of Chemical ENgineering Procces Technology, 6 (5), 256-261

Yahyaee R, Ghobadian B, Najafi G (2013). "Waste fish oil biodiesel as a source of renewable fuel in Iran", Renewable and Sustainable Energy Reviews, Cilt 17, 312-319, 2013. 